\title{
INITIAL STAGES OF INFECTIOUS PROCESS OF Pseudomonas syringae pv. garcae IN COFFEE LEAVES
}

\author{
José Otávio Gusmão de Souza ${ }^{1}$, Edson Ampélio Pozza², Leônidas Leoni Belan³ \\ Marcelo Loran de Oliveira Freitas ${ }^{4}$, Júlia Marques Oliveira ${ }^{5}$
}

(Received: May 09, 2019; accepted: June 21, 2019)

\begin{abstract}
Bacterial blight of coffee (Pseudomonas syringae pv. garcae) (PSG) has been causing damage and losses to coffee growing. However, initial stages of the infectious process should be described in order to understand the relationship cycle and to propose efficient management strategies. This study described the initial stages of infectious process of the PSG in coffee leaves over time. The bacterial penetration sites studied were stomata, leaf margins, and wounds. Coffee seedlings received $50 \mu \mathrm{L}$ inoculum suspension at marked points on the abaxial face and leaf margins, and around wounds. By 30 minutes, $1,3,6$, and 12 hours after inoculation, leaf disks collected at inoculated points were analyzed with scanning electron microscopy. One hour after inoculation, bacterial groups could be seen as result of cell multiplication. Subsequently, the number of grouped bacteria increased proportionally over time. A growing population concentration was found near stomata, wounds, epidermal appendages, and wax layer on leaf margins and leaf tip. From these places bacteria were positioned in their long axis starting from structures, thus created a population gradient and displacement flow toward penetration sites. Initial stages of infectious process occurred in all penetration sites, thus it was not possible to determine a preferred pathway.
\end{abstract}

Index terms: Scanning electron microscopy, stomata, hydathodes, Coffea arabica, bacterial blight.

\section{ESTÁGIOS INICIAIS DO PROCESSO INFECCIOSO DE Pseudomonas syringae pv. garcae EM FOLHAS DE CAFEEIRO}

RESUMO: A mancha aureolada do cafeeiro (Pseudomonas syringae pv. garcae) (Psg) tem causado danos e perdas à atividade cafeeira. Porém é necessário caracterizar as etapas iniciais do processo infeccioso para compreender o ciclo das relações e propor estratégias eficientes de manejo. Logo, o objetivo desse estudo foi caracterizar, ao longo do tempo, o processo infeccioso de Psg em folhas de cafeeiro. Os sítios de penetração bacteriana estudados nas folhas de cafeeiro foram: estômatos, bordas do limbo foliar e ferimentos. Mudas de cafeeiro foram inoculadas via deposição de $50 \mu \mathrm{L}$ de suspensão de inóculo em pontos marcados na face abaxial, nas bordas das folhas, e em pontos ao redor de ferimentos. Decorridos $30 \mathrm{~min}, 1,3$, 6 e $12 \mathrm{~h}$ após a inoculação (hai), foram coletados discos foliares nos pontos marcados e analisados por microscopia eletrônica de varredura. Decorrida 1 hai já haviam grupos bacterianos, resultado da multiplicação celular. Houve, posteriormente, aumento proporcional ao tempo, do número de bactérias agrupadas. Foi encontrada grande concentração populacional próximo a estômatos, ferimentos, em placas de cera nas bordas das folhas, em apêndices epidérmicos e em placas de cera no ápice foliar e estas criavam um gradiente populacional e um sentido e fluxo de deslocamento para as vias de penetração. As fases iniciais do processo infeccioso ocorreram em todos os sítios de penetração analisados, logo, não foi possível caracterizar uma via preferencial.

Termos para indexação: Microscopia eletrônica de varredura, estômatos, hidatódios, Coffea arabica, mancha aureolada.

\section{INTRODUCTION}

Brazil is the largest producer and exporter of coffee (USDA 2017), with approximately 2.16 million hectares planted and estimated production for 2018/2019 crop of 63.4 million $60-\mathrm{kg}$ bags (USDA 2018; CONAB 2019). However, coffee crop is subject to several diseases caused by different etiological agents (Gaitán et al. 2015) capable of reducing yields.

Bacterial blight of coffee (Pseudomonas syringae pv. garcae (Amaral et al. 1956) Young, Dye \& Wilkie 1978) has occurred frequently, causing crop damage and losses in major coffee growing regions in Brazil (Matielo and Almeida
2011; L. M. R. Rodrigues et al. 2013; Maciel et al. 2012; G. H. Sera et al. 2004) and other countries (Chen 2002; Korobko and Wondimagegne 1997; Ramos and Shavdia 1976). Bacterial blight was initially considered of secondary importance (Amaral et al. 1956); however, the pathogen has rapidly disseminated and disease has been occurring at high progress rates in coffee areas in the states of Paraná, São Paulo and Minas Gerais - Brazil (Matielo and Almeida 2011; G. H. Sera et al. 2004; T. Sera et al. 2002; Zoccoli et al. 2011). Infected seedlings and infested harvesters are the main forms of long-distance dissemination. Mechanized harvesting can spread bacteria within crops as well as raindrops, irrigation, and

1,2,3,4,5Universidade Federal de Lavras/UFLA - Departamento de Fitopatologia/DFP - 37.200-000 - Lavras - MG joseotavio_goncalves@yahoo.com.br, edsonpozza@gmail.com, leonidas_agronomia@yahoo.com.br, marceloloran@yahoo.com.br, julia.moliveira@ymail.com 
hail (Agrios 2005; Pozza et al. 2010; L. M. R. Rodrigues et al. 2013). The etiological agent can also be associated with seeds (Belan et al. 2016), providing its dissemination to the seedling nursery. Pathogen presence in plants during your epiphytic phase, under favorable environmental conditions, causes bacterial multiplication, cell aggregate formation, and plant surface colonization (Goto 2012; Romantschuk 1992; Romeiro 2005; Scortichini 1995). Then, bacteria can spread on plant surfaces with the help of flagella (Belan et al. 2016; L L Belan et al. 2014) until reaching a penetration pathway.

P. syringae pv garcae (PSG) and other plant pathogenic bacteria depend on penetration pathways to reach host internal tissues, either natural openings such as stomata and hydathodes, or artificial openings such as wounds (Goodman 1982; Romeiro 2005). In the field, blight lesions occur randomly on the blade or margins of coffee leaves, characterizing penetration through natural wounds or openings (Leônidas L Belan et al. 2014; L. M. R. Rodrigues et al. 2013; Ito et al. 2008). These pathways can provide exudation of water and nutritive compounds, which are attractive to bacteria. Wounds may be as important or even more important to bacterial infection than natural openings because, in addition to exteriorizing cell nutritional content and attracting plant pathogenic bacteria, wounds provide direct access to host intercellular spaces, thus enabling the infectious process to start (Madigan et al. 2017; Romeiro 2005).

However, due to rapid bacteriamultiplication and consequent high progress rate of epidemics (L L Belan et al. 2014; Cabrefiga and Montesinos 2005; Carmo et al. 1996; Gottwald et al. 2010; Gottwald et al. 1989), describing initial stages of infectious process is necessary to understand the cycle of pathogen/host interactions. Scanning electron microscopy (SEM) has been useful for displaying stages of the plant pathogenic bacteria infectious process in diverse pathosystems (Amponsah et al. 2012; Getz et al. 1983; Huang 1986; Kroupitski et al. 2009; Roos and Hattingh 1987), as the technique provides detailed images. Neto et al. (2006) analyzed the penetration and colonization of Acidovorax avenae subsp. citrulli in melon (Cucumis melo L.), describing aggregate formation on leaf epidermis in fruits and seeds of melon 24 hours after inoculation. Characterizing infectious processes makes it possible to identify preferred penetration pathways and propose efficient strategies for artificial pathogen inoculation in experimental trials. It is also possible to propose specific management strategies, such as minimizing injuries during harvesting and farming practices, installing barriers to avoid direct wind incidence, and using chemical pesticide to prevent and cure infection.

Thus, the goal of this study was to describe the initial stages of infectious process of the PSG in coffee leaves over time.

\section{MATERIAL AND METHODS}

\section{PSG inoculation}

Coffee seedlings (C. arabica) of cultivar Catuaí Vermelho IAC 99 with five pairs of leaves were placed in a plant growth chamber with controlled temperature $23 \pm 2^{\circ} \mathrm{C}$, relative humidity $70 \%$ and 12-hour photoperiod (light and dark). Plants remained in horizontal position on a stand for 24 hours prior to inoculation and throughout the experimental period.

Seedlings were inoculated with sub-culture of reference isolate P. syringae pv. garcae (CIRM - Plant Associated Bacteria / CIRM-CFBP1634) from the bacterial culture collection of the Department of Plant Pathology, Federal University of Lavras. Inoculum was prepared with pathogen seeding in 523 medium (Kado and Heskett 1970), growed in a BOD incubator at $28 \pm 2^{\circ} \mathrm{C}$ and 12-hour photoperiod. After 48 hours, bacterial cells were suspended in sterile saline solution $(\mathrm{NaCl} 0.85 \%)$ and bacterial concentration was determined with spectrophotometer at $600 \mathrm{~nm}$ (OD ${ }_{600}$ ), as described by Oliveira and Romeiro (1990). Bacterial cell suspension was prepared by dilution in sterile saline solution at concentration $1.1 \times 10^{9}$ UFC. $\mathrm{mL}^{-1}$ calibrated with spectrophotometer $(0.2$ absorbance) (Oliveira and Romeiro 1990).

Inoculation was performed at circle marks on blades of fully expanded leaves of first and second pairs from seedling apex. Bacterial penetration sites assessed were stomata, leaf blade margins, and artificial wounds. To examine the infectious process by stomata and possible openings on leaf margins, several points were randomly marked on the abaxial surface and blade borders, and 50 $\mu \mathrm{L}$ inoculum suspension was deposited per point. Wound penetration was assessed by immersing a ten-needle set (multi-needles) fixed in resistant structure in inoculum suspension to puncture leaves. Control plant leaves were inoculated likewise with sterile saline solution ( $\mathrm{NaCl} 0.85 \%)$.

\section{Collection of biological material}

Biological material was collected at previously inoculated points on leaf blades. Leaf 
tissue samples were taken with a 5-mm diameter disk punch from each penetration site after 30 minutes, 1, 3, 6, and 12 hours of inoculation. Controls were sampled by 12 hours after inoculation.

Leaf disks were immersed in modified Karnovsky's fixative $(2.5 \%$ glutaraldehyde, $2.5 \%$ formaldehyde in $0.05 \mathrm{M}$ sodium cacodylate buffer, $\mathrm{pH} 7.2,0.001 \mathrm{M} \mathrm{CaCl}_{2}$ ) for 24 hours and conditioned in $1.5 \mathrm{~mL}$ Eppendorf tubes. After fixation, samples were immersed for 10 minutes in cacodylate buffer solution $(0.05 \mathrm{M})$ and washed three times. Samples were then post-fixed in $1 \%$ osmium tetroxide solution in $0.05 \mathrm{M}$ cacodylate buffer, $\mathrm{pH} 7.2$ for 1 hour, and immersed in distilled water for 10 minutes for three times. Then, samples were dehydrated in acetone solutions $(25 \%, 50 \%$, $75 \%, 90 \%$, and $100 \%$ ) and dried to the critical point with liquid $\mathrm{CO}_{2}$ in Balzers CPD 030. Next, four leaf disks from each treatment were fixed to stubs with carbon tape and gold-coated (Balzers SCD 050) for analysis with LEO EVO 40 SEM.

Images were digitally generated and captured at $20 \mathrm{Kv}$ and distance ranging from 9 to $12 \mathrm{~mm}$. The goal was to locate and visualize bacterial cells and colonies, their multiplication and displacement on leaf surface, and penetration through natural openings or wounds. Image analysis to characterize PSG infectious process in coffee leaves was performed with CorelDRAW ${ }^{\circledR}$ Photo-Paint 12. Several images were obtained, but only the ones that best represented the process were used.

\section{RESULTS AND DISCUSSON}

PSG multiplication with increasing population and aggregate formation were seen around wounds and natural structures, stomata, and epidermal appendages over time (Fig. 1, 2, 3 and 4).

By 30 minutes after inoculation, bacteria from the initial inoculum were seen dispersed on the leaf blade (Fig. 1B, 2B, 3B, 4B). By 1 hour after inoculation, cell multiplication (Fig. 1C, 4C) and aggregated bacteria (bacterial groups) were detected around stomata, wounds and wax layers on leaf margins (Fig. 1C, 2C, 4C). However, 3 hours after inoculation aggregates were larger than they were at 1 hour after inoculation. A distribution gradient was starting from stomata, wounds, and wax layers on leaf margins, and from epidermal appendages and wax layers in leaf tip, indicating a displacement flow toward penetration pathways (Fig. 1D, 2D, 3D, 4D). Bacteria were also directed to pathways in their long length or cell axis. By 6 and 12 hours after inoculation, the number of grouped bacteria (Fig. 1E, 1F, 2E, 2F, $3 \mathrm{E}, 3 \mathrm{~F}, 4 \mathrm{E}, 4 \mathrm{~F})$ at those sites increased over time, during biofilm formation. At the leaf margins, for example, 9, 13, 30, 32 and 66 bacterial cells were identified at $30 \mathrm{~min}, 1,3,6$ and 12 hours post inoculation, respectively (Fig. 4A - F).

No bacteria were found in leaf samples from control plants (Fig.1A, 2A, 3A and 4A).

Biofilm formation during the epiphytic phase of PSG is as important part of the preinfection stage of the pathogen. PSG initial inoculum had accumulated in epidermal depressions and fissures of wax layers, forming a biofilm that favors displacement to the penetration site, multiplication and colonization on surface during initial stages of infectious process in coffee leaves (Amorim and Pascholati 2011; Marcuzzo and Denardim 2008; Romantschuk 1992; Romeiro 2005). Inoculum retention is related to cuticular morphology and topography of leaves. Lichston and Godoy (2006) described a discontinuous filmlike layer of wax with ruptures along the cuticle in coffee leaves (Coffea arabica) of Catuaí Vermelho cultivar, which may favor bacterial cell retention. The present study also found this result in leaf ends. However, cuticular wax does not degrade to provide nutrients to pathogens (Marcell and Beattie 2002). Analyzing the effect of cuticular characteristics on colonization of Pantoea agglomerans and Clavibacter michiganensis in corn leaves, these authors described wax layer only as a contributing factor for nutrient and water distribution in leaves. Wax layer also contributes to nutrient and water accumulation to provide a favorable environment for bacterial reproduction and population increase over time (Marcell and Beattie 2002; Monier and Lindow 2004; Neto et al. 2006).

In addition to pathway conformation, substance exudation from wounds and natural openings also favor plant pathogenic bacteria infectious process (Madigan et al. 2017; Romeiro 2005). Wounds cause leakage of cell fluids and stomata exude photosynthesized organic compounds such as glucose. As described by Fiala et al. (1990), Mercier and Lindow (2000) and Marcell and Beattie (2002), nutrient compounds reach leaf surface but are repelled on the epidermis, since wax is hydrophobic. These nutrients create a flow which induce microorganism grouping near, or in, wax layers as seen in leaf tip and margins. 


\section{Stomata}

Control

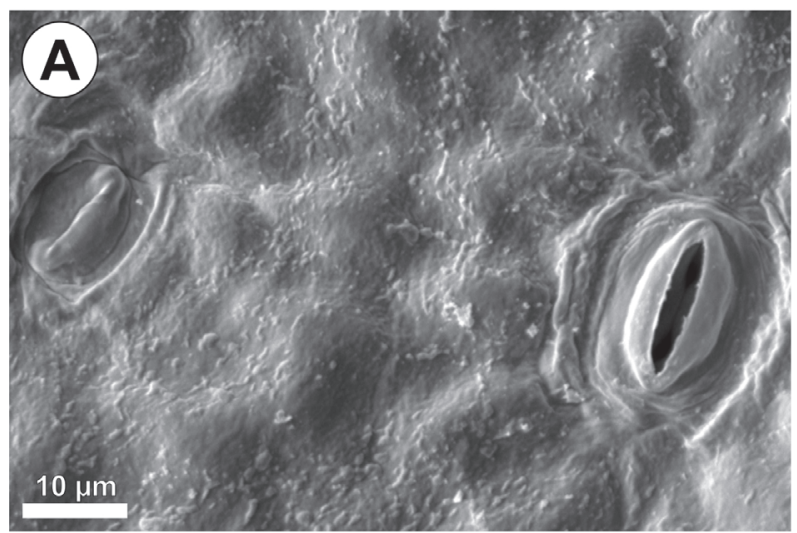

1 hai
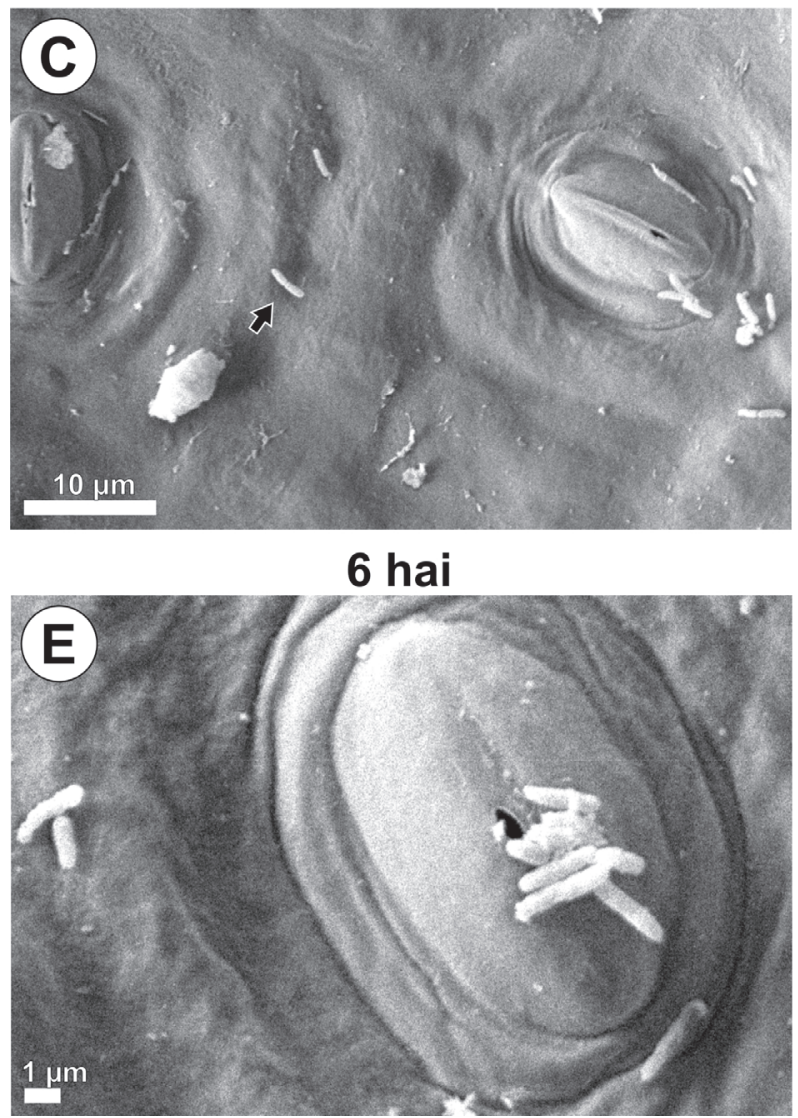

$30 \mathrm{~min}$

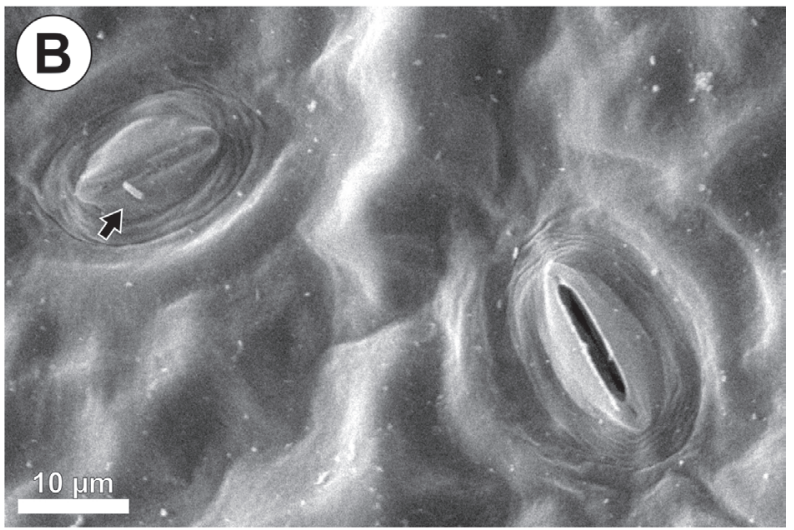

3 hai

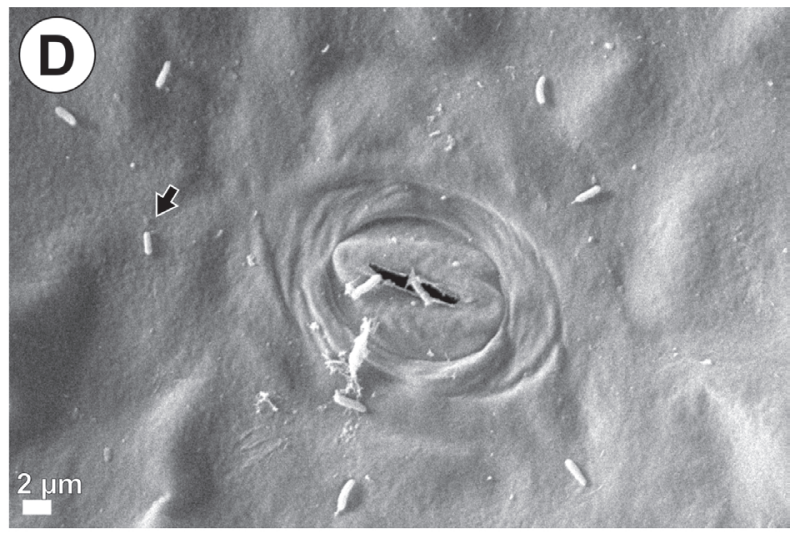

12 hai

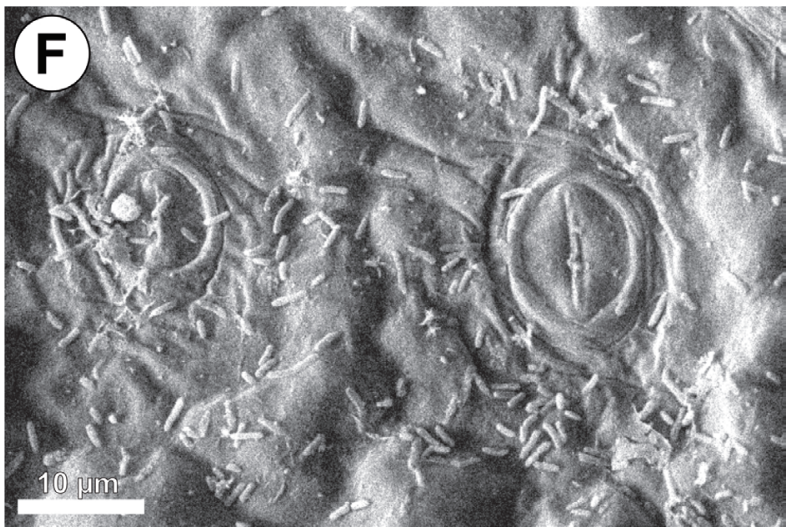

FIGURE 1 - Scanning electron microscope images of Pseudomonas syringae pv. garcae around stomata on coffee leaves (Coffea arabica) during the infectious process. Hai: Hours after inoculation. Arrows indicate bacterial cells. 


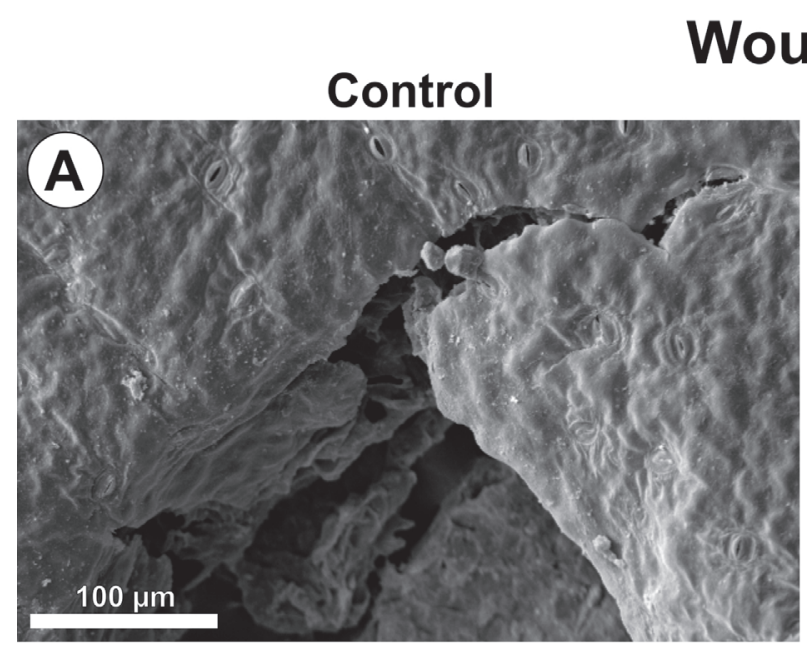

1 hai

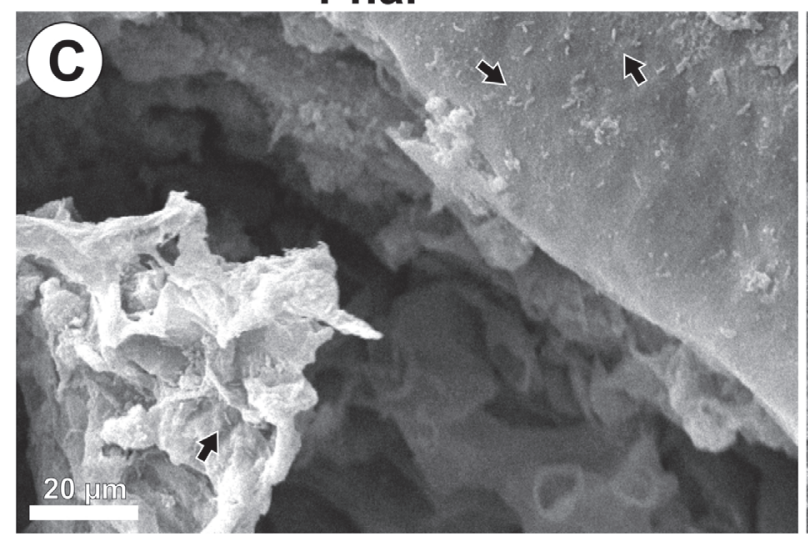

6 hai
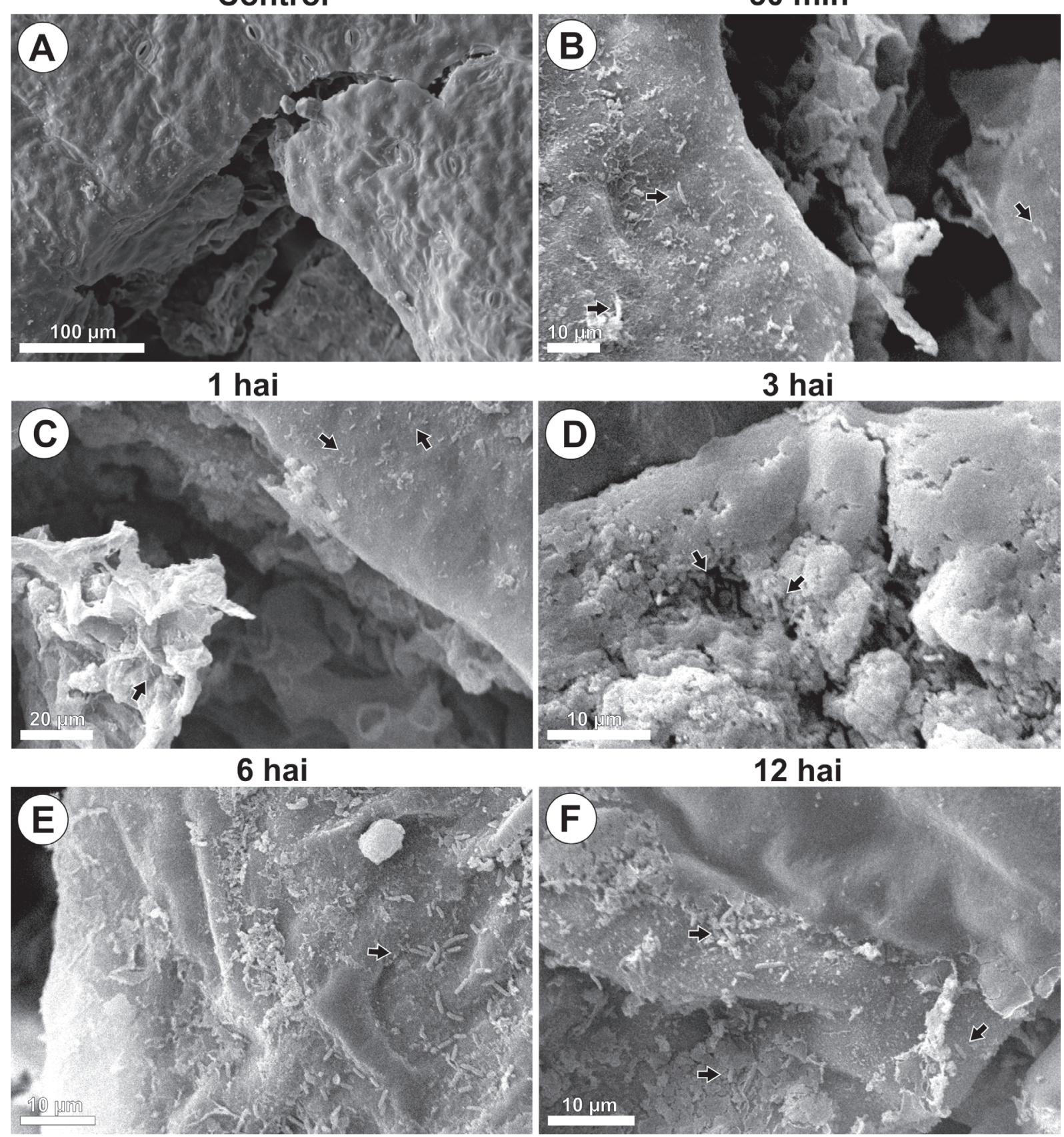

\section{$30 \mathrm{~min}$}

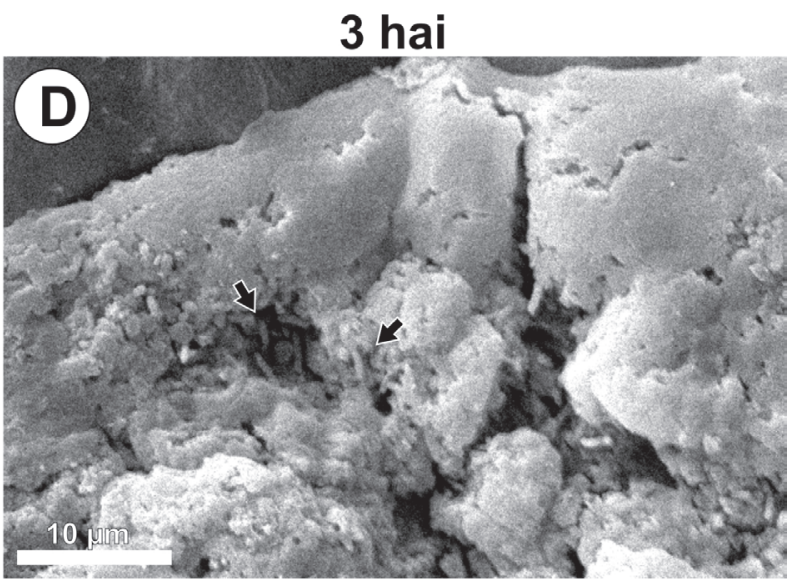

12 hai

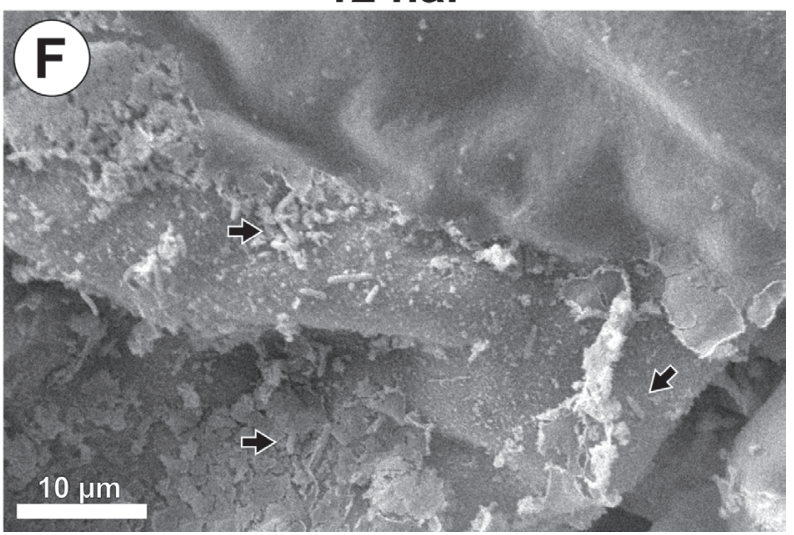

FIGURE 2 - Scanning electron microscope images of Pseudomonas syringae pv. garcae around wounds on coffee leaves (Coffea arabica) during the infectious process. Hai: Hours after inoculation. Arrows indicate bacterial cells. 

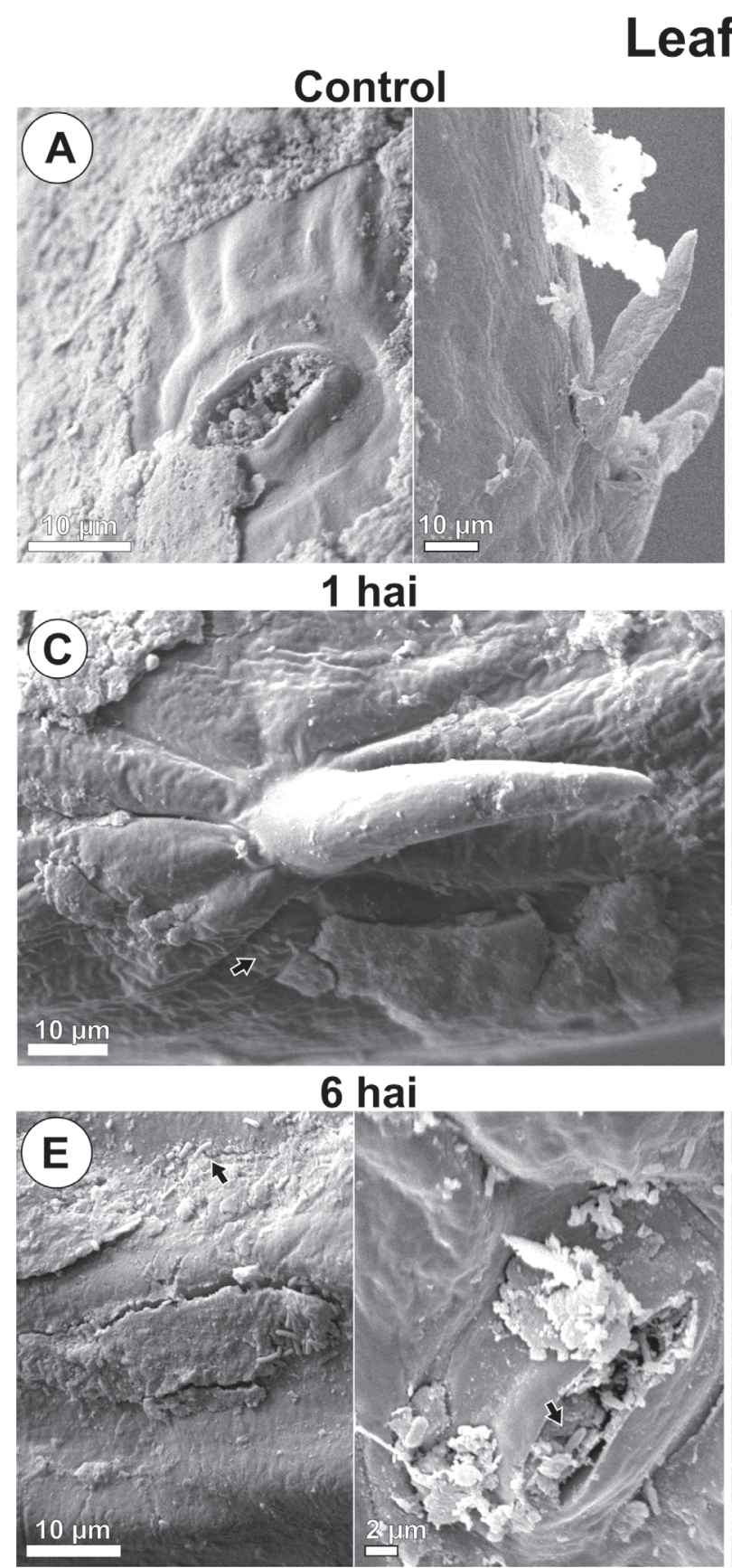

$30 \mathrm{~min}$

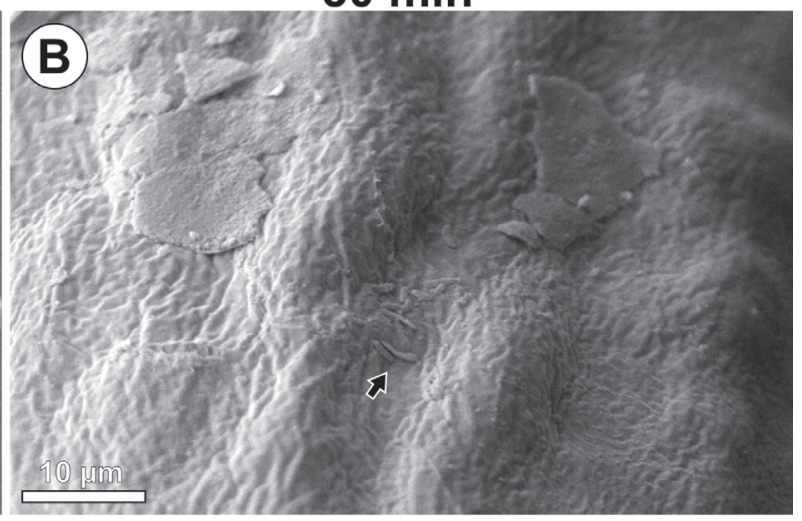

3 hai

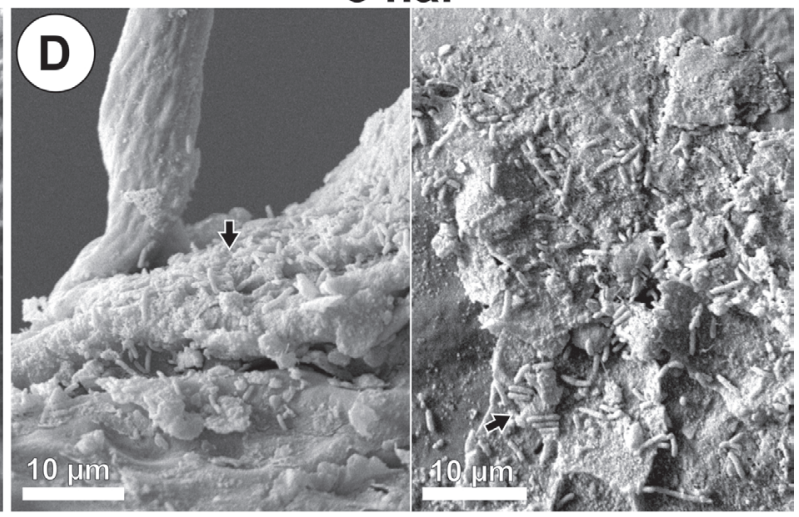

12 hai

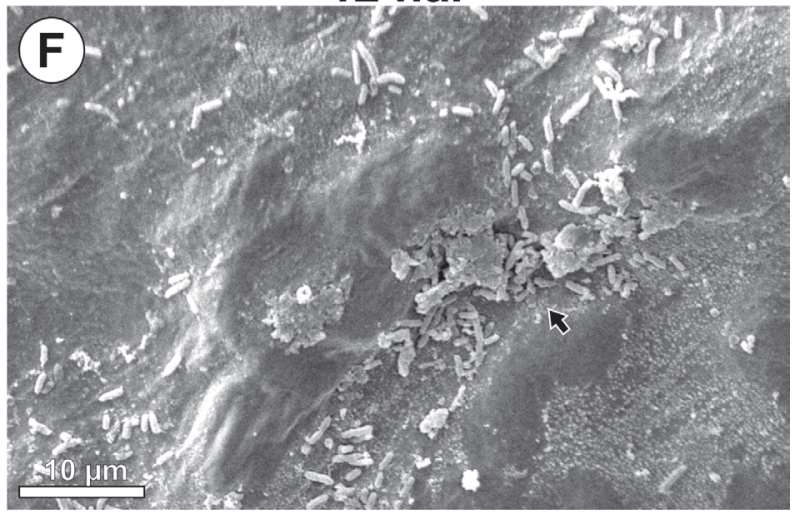

FIGURE 3 - Scanning electron microscope images of Pseudomonas syringae pv. garcae around leaf tip on coffee leaves (Coffea arabica) during the infectious process. Hai: Hours after inoculation. Arrows indicate bacterial cells. 


\section{Leaf Margin}

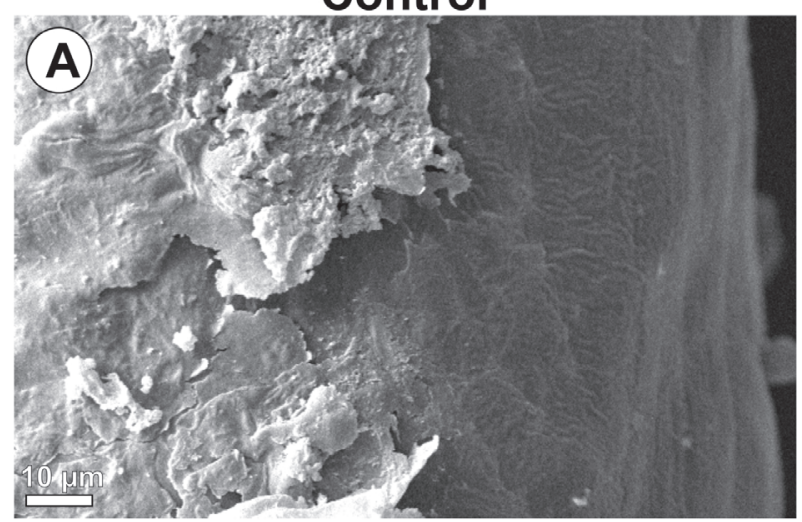

1 hai

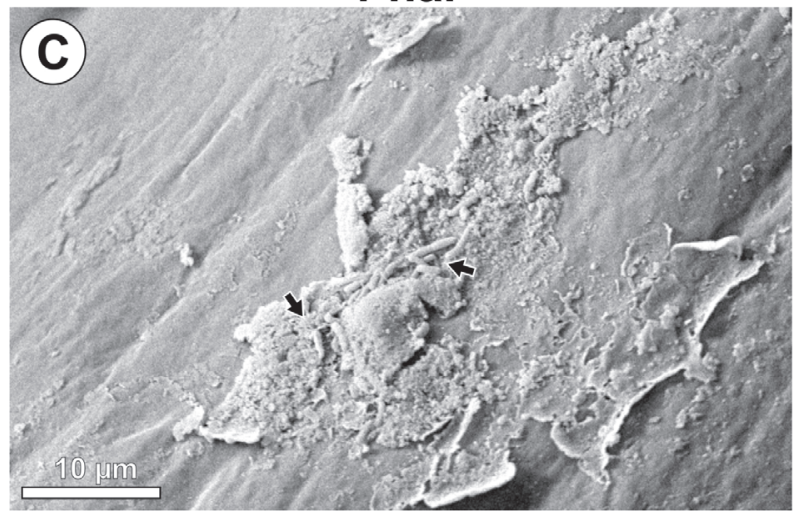

6 hai

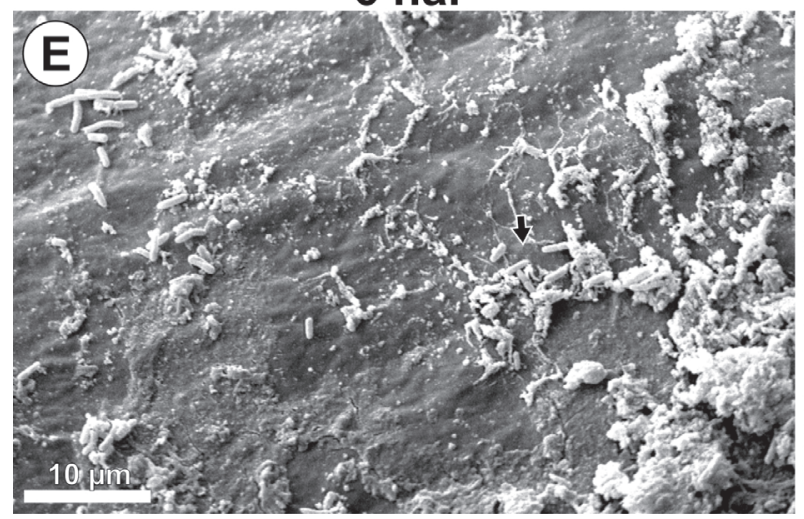

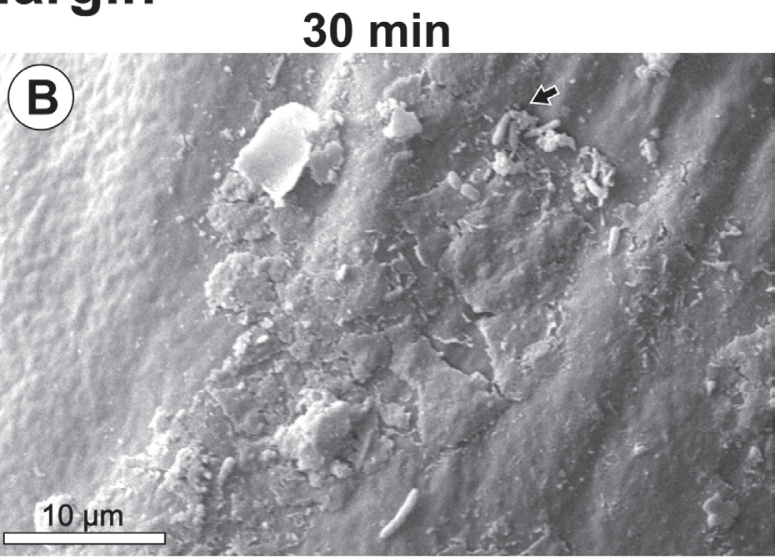

3 hai

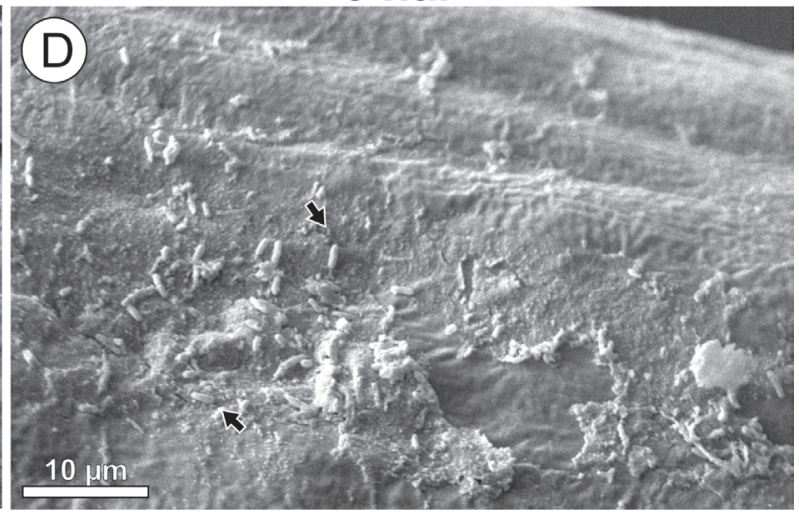

12 hai

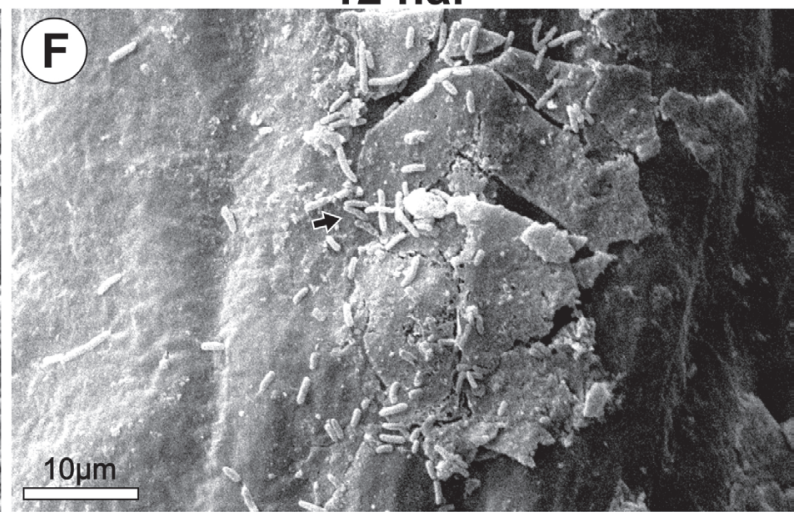

FIGURE 4 - Scanning electron microscope images of Pseudomonas syringae pv. garcae around leaf margin on coffee leaves (Coffea arabica) during the infectious process. Hai: Hours after inoculation. Arrows indicate bacterial cells.

Thus, nutrients attract bacteria and induce positive tactic movement toward penetration sites in plant tissue (Agrios 2005; Romeiro 2005). Coffee leaves showed a gradient of PSG concentration starting from wound margins and stomata. Bacterial cells were predominantly oriented in their long length toward exposed parenchyma and natural openings, indicating attraction and flagella movement. Similarly, Kroupitski et al. (2009) demonstrated Salmonella enterica penetration through stomata of lettuce leaves only when plants were exposed to light, thus producing sugars, that is, chemoattractant substances. In contrast to saprophytic, plant pathogenic bacteria only react to substances produced at host infection site, as they have specific chemoreceptors to recognize 
these substances and consequently target the site (Amorim and Pascholati 2011; Chet et al. 1973; de Weert et al. 2002; Yao and Allen 2006). The results in the present study confirm this behavior.

Before those studies, only epidermal appendages had been described around domatia in coffee leaves (Dedecca 1957; Nakamura et al. 1992). However, appendages similar to trichromes were identified in leaf tip with groups of PSG cells around them. Schneider and Grogan (1977) and Getz et al. (1983) justify such distribution and bacterial behavior by describing foliar topography around trichromes as a favorable site for nutrient concentration and plant pathogenic bacteria survival until infection, as found for PSG in coffee leaves. Mew et al. (1984) and Monier and Lindow (2004) also reported aggregate formation in leaf trichromes of rice and bean plants inoculated with Xanthomonas campestris pv. oryzae and $P$. syringae pv. syringae, respectively. However, the authors suggested a possible nutrient exudation by these structures or sites.

The apex of coffee leaves also showed structures morphologically similar to hydathodes, with population gradient of PSG around and inside them. PSG occupation of those structures contributes to bacterial blight symptoms occurring frequently in the leaf tip in both field and seedling nurseries (Leônidas L Belan et al. 2014; Godoy et al. 1997; Ito et al. 2008; Pozza et al. 2010; L. M. R. Rodrigues et al. 2013). In this sites Psg grew exponentially, increasing its population 7.3 times between 30 minutes and 12 hours after inoculation. Bacterial grouping around hydathodes has been described in other cultures. Mew et al. (1984) analyzed the behavior of $X$. campestris pv. oryzae in rice plants, reporting 1 hour after incubation the presence of aggregate-forming bacteria and population gradient around hydathodes, as found for PSG around similar structures in coffee leaves. The internal space of such structures is colonized by Clavibacter michiganensis subsp. michiganensis before penetration in tomato leaves, as demonstrated by Carlton et al. (1998). Bacterial aggregates were associated with fissures in the wax layer in the same area of coffee leaves, thus confirming the hypothesis of these structures functioning as PSG penetration sites.

The present study showed the initial stages of infectious process of PSG in coffee leaves starting from 1 to 3 hours after inoculation, which characterized rapid infection capacity. However, it was not possible to identify symptoms of disease in inoculated leaves during these stages of infectious process. L.M.R. Rodrigues et al. (2015) reported morphological alterations in tissue cells of coffee leaves infected with PSG; however, evaluations were performed 10 days after inoculation, when leaves already showed necrotic symptoms. Other researchers have also investigated the relationship between bacterial pathogens and respective hosts over time during infectious process, however with sampling intervals ranging from 24 hours to 21 days after inoculation (Carlton et al. 1998; Getz et al. 1983; Monier and Lindow 2004; Neto et al. 2006; Schneider and Grogan 1977). Thus, there was no experimental pattern regarding time to start evaluating infectious process after inoculation or manifestation of disease symptoms in plants. In the present study, early evaluations performed between 1 and 12 hours after incubation provided a better understanding of PSG infectious process in coffee leaves and showed all sites inoculated are potential pathways to infection.

In addition, there is not standard regarding a preferred penetration pathway for plant pathogenic bacteria, regardless of crop or infected plant organ. According to Romeiro (2005), wounds are more favorable to pathogen penetration than natural openings. However, as demonstrated by Neto et al. (2006) Acidovorax avenae subsp. citrulli penetrated melon leaves preferentially by stomata. In citrus leaves, Belasque Junior et al. (2008) found no difference in manifestation of citrus canker symptoms ( $X$. citri subsp. citri), irrespective of penetration route. This variability regarding a preferential site justifies the present study and the adoption of farming practices that reduce the incidence of wounds in addition to the preventive applications of protective pesticides, or after harvest and hailstorm.

\section{CONCLUSIONS}

Bacterial cells of inoculum were retained in epidermal depressions and fissures in wax layers on leaf surface.

By 1 hour after incubation, bacterial groupings were already seen as result of cell multiplication. Subsequently, the number of grouped bacteria increased over time, practically exponentially, starting 30 minutes after inoculation.

A great population concentration was found near stomata, wounds, wax layers on leaf margins, epidermal appendages, and wax layers in leaf tip. Bacteria were positioned in their long axis starting from these structures, which created a population gradient, that is, a displacement flow to penetration sites. Initial stages of infectious process occurred in all penetration sites, thus it was not possible to describe a preferred pathway. 


\section{ACKNOWLEDGMENTS}

Thanks to the Conselho Nacional de Desenvolvimento Científico e Tecnológico (CNPq), the Instituto Nacional de Ciência e Tecnologia do café (INCT-Coffee), and the Fundação de Amparo à Pesquisa do Estado de Minas Gerais (FAPEMIG) for contributing with this study.

\section{REFERENCES}

Agrios, G. N. (2005). Plant pathology (Vol. 5th). Burlington. Mass, EUA: Elsevier Acad. Press. .

Amaral, J. F., Teixeira, C., \& Pinheiro, E. D. (1956). A bactéria causadora da mancha aureolada do cafeeiro. Arquivos do Instituto Biológico, 23, 151.

Amorim, L., \& Pascholati, S. F. (2011). Ciclo de relações patógeno-hospedeiro. In L. Amorin, J. Rezende, \& A. Filho (Eds.), Manual de Fitopatologia, (Vol. 1, pp. 59100). Piracicaba: Agronômica Ceres.

Amponsah, N. T., Jones, E. E., Ridgway, H. J., \& Jaspers, M. V. (2012). Microscopy of some interactions between Botryosphaeriaceae species and grapevine tissues. Australasian Plant Pathology, 41(6), 665673.

Belan, L. L., Pozza, E. A., Freitas, M. L. O., Raimundi, M. K., Souza, R. M., \& Machado, J. C. (2016). Occurrence of Pseudomonas syringae pv. garcae in coffee seeds. Australian Journal of Crop Science, 10(7), 1015, doi:10.21475/ajcs.2016.10.07.p7693.

Belan, L. L., Pozza, E. A., Freitas, M. L. O., Souza, R. M., Jesus Junior, W. C., \& Oliveira, J. M. (2014). Diagrammatic scale for assessment of bacterial blight in coffee leaves. Journal of Phytopathology, 162(1112), 801-810, doi:10.1111/jph.12272.

Belan, L. L., Pozza, E. A., \& Souza, R. M. (2014). A Mancha Aureolada do Cafeeiro. Revisão Anual de Patologia de Plantas, 22, 227-256.

Belasque Junior, J., Jaciani, F. J., Marin, D. R., \& Barbosa, J. C. (2008). Tamanho da amostra para quantificação do diâmetro de lesões de cancro cítrico. Tropical Plant Pathology, 33(4), 317-322.

Cabrefiga, J., \& Montesinos, E. (2005). Analysis of aggressiveness of Erwinia amylovora using diseasedose and time relationships. Phytopathology, 95(12), 1430-1437.
Carlton, W. M., Braun, E. J., \& Gleason, M. L. (1998). Ingress of Clavibacter michiganensis subsp. michiganensis into tomato leaves through hydathodes. Phytopathology, 88(6), 525-529.

Carmo, M. G. F., Kimura, O., Maffia, L. A., \& Carvalho, A. (1996). Progresso da pústula bacteriana do pimentão, causada por Xanthomonas campestris $p v$. vesicatoria em condições de viveiro. Fitopatologia Brasileira, 20, 66-70.

Chen, Z. (2002). Morphocultural and pathogenic comparisons between Colletotrichum kahawae and C. gloeosporioides isolated from coffee berries Univ Techn de Lisboa, Lisboa, Portugal.

Chet, I., Zilberstein, Y., \& Henis, Y. (1973). Chemotaxis of Pseudomonas lachrymans to plant extracts and to water droplets collected from the leaf surfaces of resistant and susceptible plants. Physiological Plant Pathology, 3(4), 473-479.

CONAB (2019). Companhia Nacional de Abastecimento. Acompanhamento da safra brasileira de café, v. 4 - Safra 2019 - Quarto Levantamento Available in: < https://www.conab.gov.br/info-agro/ safras/cafe >. Accession: June /18/2019,

de Weert, S., Vermeiren, H., Mulders, I. H. M., Kuiper, I., Hendrickx, N., Bloemberg, G. V., et al. (2002). Flagella-driven chemotaxis towards exudate components is an important trait for tomato root colonization by Pseudomonas fluorescens. Molecular Plant-Microbe Interactions, 15(11), 1173-1180.

Dedecca, D. M. (1957). Anatomia e desenvolvimento ontogenético de Coffea arabica L. var. typica Cramer. Bragantia, 16(23), 315-366.

Fiala, V., Glad, C., Martin, M., Jolivet, E., \& Derridj, S. (1990). Occurrence of soluble carbohydrates on the phylloplane of maize (Zea mays L.): variations in relation to leaf heterogeneity and position on the plant. New Phytologist, 115(4), 609-615.

Gaitán, A. L., Cristancho, M. A., Castro Caicedo, B. L., Rivillas, C. A., \& Gómez, G. C. (2015). Compendium of coffee diseases and pests. St. Paul, MN.: APS Press, The American Phytopathological Society.

Getz, S., Fulbright, D. W., \& Stephens, C. T. (1983). Scanning electron microscopy of infection sites and lesion development on tomato fruit infected with Pseudomonas syringae pv. tomato. Phytopathology, 73(1), 39-43. 
Godoy, C. V., Bergamin Filho, A., \& Salgado, C. L. (1997). Doenças do cafeeiro (Coffea arabica L.). In H. Kimati (Ed.), Manual de Fitopatologia (pp. 184200). São Paulo: Agronômica Ceres.

Goodman, R. N. (1982). The infection process. In M. S. Mount, \& G. H. Lacy (Eds.), Phytopathogenic prokaryotes (Vol. 1, pp. 31-62). New Yor: Academic Press.

Goto, M. (2012). Fundamentals of bacterial plant pathology: Academic Press.

Gottwald, T. R., Irey, M. S., Gast, T., Parnell, S. R., Taylor, E., \& Hilf, M. Spatio-temporal analysis of an HLB epidemic in Florida and implications for spread. In International Organization of Citrus Virologists Conference Proceedings (1957-2010), 2010 (Vol. 17, Vol. 17)

Gottwald, T. R., Timmer, L. W., \& McGuire, R. G. (1989). Analysis of disease progress of Citrus canker in nurseries in Argentina. Phytopathology, 79(11), 1276-1283.

Huang, J. (1986). Ultrastructure of bacterial penetration in plants. Annual review of phytopathology, 24(1), 141-157.

Ito, D. S., Sera, T., Sera, G. H., Del Grossi, L., \& Kanayama, F. S. (2008). Resistance to bacterial blight in arabica coffee cultivars. Crop Breeding and Applied Biotechnology, 8(2), 99-103.

Kado, C. I., \& Heskett, M. G. (1970). Selective media for isolation of Agrobac-terium, Corynebacterium, Erwinia, Pseudomonas, and Xanthomonas. Phytopathology, 60(6), 969-976.

Korobko, A., \& Wondimagegne, E. (1997). Bacterial blight of coffee (Pseudomonas syringae pv. garcae) in Ethiopia. In K. Rudoldh, T. J. Burr, J. W. Mansfield, D. Stead, A. Vivian, \& J. Von Kietzele (Eds.), Pseudomonas Syringae Pathovars and Related Pathogens (pp. 538-541). Netherlands: Springer.

Kroupitski, Y., Golberg, D., Belausov, E., Pinto, R., Swartzberg, D., Granot, D., et al. (2009). Internalization of Salmonella enterica in leaves is induced by light and involves chemotaxis and penetration through open stomata. Applied and environmental microbiology, 75(19), 6076-6086.

Lichston, J. E., \& Godoy, S. A. P. (2006). Morfologia e teor de cera de folhas de café após aplicação de fungicida. Pesquisa Agropecuária Brasileira, 41(6), 919-926.
Maciel, K. W., Almeida, I. M. G., Patrício, F. R. A., Pierini, V., Rodrigues, L. M. R., \& Beriam, L. O. S. (2012). Caracterização Serológica de Pseudomonas syringae pv.garcae, Agente Causal da "Mancha Aureolada" do Cafeeiro. Tropical Plant Pathology, 37 (Suplemento), 510.

Madigan, M. T., Bender, K. S., Buckley, D. H., Sattley, W. M., \& Stahl, D. A. (2017). Brock Biology of Microorganisms (Vol. 15): Pearson.

Marcell, L. M., \& Beattie, G. A. (2002). Effect of leaf surface waxes on leaf colonization by Pantoea agglomerans and Clavibacter michiganensis. Molecular plant-microbe interactions, 15(12), 12361244.

Marcuzzo, L. L., \& Denardim, N. D. (2008). Colonização de bactérias causadoras de doenças foliares. Revista de Ciências Agroveterinárias, 7(2), 169-176.

Matielo, J. B., \& Almeida, S. R. (2011). Ataque da bacteriose mancha aureolada (Pseudomonas seryngae $p v$ garcae) se espalha nas lavouras cafeeiras. Folha Técnica: Fundação Procafé.

Mercier, J., \& Lindow, S. E. (2000). Role of leaf surface sugars in colonization of plants by bacterial epiphytes. Applied and Environmental Microbiology, 66(1), 369-374.

Mew, T. W., Mew, I. C., \& Huang, J. S. (1984). Scanning electron microscopy of virulent and avirulent strains of Xanthomonas campestris pv. oryzae on rice leaves. Phytopathology, 74(6), 635-641.

Monier, J. M., \& Lindow, S. E. (2004). Frequency, size, and localization of bacterial aggregates on bean leaf surfaces. Applied and environmental microbiology, 70(1), 346-355.

Nakamura, T., Taniguchi, T., \& Maeda, E. (1992). Leaf anatomy of Coffea arabica L. with reference to domatia. Japanese Journal of Crop Science, 61(4), $642-650$.

Neto, E. B. S., Silveira, E. B., Mariano, R. L. R., Nogueira, N. L., Rossi, M. L., \& Santos, L. A. (2006). Penetração e colonização de Acidovorax avenae subsp. citrulli em folhas, frutos e sementes de melão amarelo. Fitopatologia Brasileira, 31, 1. 
Oliveira, J. R., \& Romeiro, R. S. (1990). Reação de folhas novas e velhas de cafeeiro a infecção por Pseudomonas cichorii e P. syringae pv. garcae. Fitopatologia Brasileira, Brasília, 15, 355-356.

Pozza, E. A., Carvalho, V. L., \& Chalfoun, S. M. (2010). Sintomas e injúrias causadas por doenças em cafeeiro. In R. J. Guimarães, A. N. G. Mendes, \& D. P. Baliza (Eds.), Semiologia do cafeeiro: sintomas de desordens nutricionais, fitossanitárias e fisiológicas (pp. 68-106). Lavras, MG: Editora UFLA.

Ramos, A., \& Shavdia, L. (1976). A dieback of coffee in Kenya. Plant Disease Reporter, 60(10), 831-835.

Rodrigues, L. M. R., Almeida, I. M. G., Patrício, F. R. A., Beriam, L. O. S., Maciel, K. W., Braghini, M. T., et al. (2013). Mancha Aureolada do Cafeeiro Causada por Pseudomonas syringae pv. garcae. Boletim Técnico Instituto Agronômico de Campinas $(I A C)(212)$.

Rodrigues, L. M. R., Queiroz-Voltan, R. B., \& Guerreiro Filho, O. (2015). Anatomical changes on coffee leaves infected by Pseudomonas syringae pv. garcae. Summa Phytopathologica, 41(4), 256-261.

Romantschuk, M. (1992). Attachment of plant pathogenic bacteria to plant surfaces. Annual review of phytopathology, 30(1), 225-243.

Romeiro, R. S. (2005). Bactérias fitopatogênicas: Universidade Federal de Viçosa.

Roos, I. M. M., \& Hattingh, M. J. (1987). Systemic invasion of cherry leaves and petioles by Pseudomonas syringae pv. morsprunorum. Phytopathology, 77(9), 1246-1252.
Schneider, R. W., \& Grogan, R. G. (1977). Tomato leaf trichomes, a habitat for resident populations of Pseudomonas tomato. Phytopathology, 67, 898-902.

Scortichini, M. (1995). Le malattie batteriche delle colture agrarie e delle specie forestali: Edagricole.

Sera, G. H., Sera, T., Altéia, M. Z., Androcioli Filho, A., Azevedo, J. A., Petek, M. R., et al. (2004). Associação de Pseudomonas syringae pv. garcae com algumas características agronômicas em cafeeiros F2 segregantes para o gene erecta. Cienc Agrotec, 28, 974-977.

Sera, T., Alteia, M. Z., Petek, M. R., \& ZAMBOLIM, L. (2002). Melhoramento do cafeeiro: variedades melhoradas no Instituto Agronômico do Paraná (IAPAR). O estado da arte de tecnologias na produção de café. Viçosa: UFV, 217-251.

USDA (2017). United States Department of Agriculture. Production, Supply and Distribuition. Available in: $<$ https://apps.fas.usda.gov/psdonline/app/index. html\#/app/downloads>. Accession: January / 08/ 2018 ,

USDA (2018). United States Department of Agriculture. Production, Supply and Distribuition. Available in: $<$ http://www.usdabrazil.org.br/pt-br/reports/coffeesemi-annual-2018.pdfs >. Accession: June / 18/ 2019

Yao, J., \& Allen, C. (2006). Chemotaxis is required for virulence and competitive fitness of the bacterial wilt pathogen Ralstonia solanacearum. Journal of bacteriology, 188(10), 3697-3708.

Zoccoli, D. M., Takatsu, A., \& Uesugi, C. H. (2011). Ocorrência de mancha aureolada em cafeeiros na Região do Triângulo Mineiro e Alto Paranaíba. Bragantia, 70(4), 843-849. 